\title{
LOOKING NORTH, LOOKING SOUTH
}

China, Taiwan, and the South Pacific 


\title{
Series on Contemporary China - Vol. 26 \\ LOOKING NORTH, LOOKING SOUTH
}

China, Taiwan, and the South Pacific

\author{
editor \\ Anne-Marie Brady \\ University of Canterbury, New Zealand
}


Series Editors: Joseph Fewsmith (Boston University)

Zheng Yongnian (East Asian Institute, National University of Singapore)

Published*

Vol. 14 Migration and Social Protection in China edited by Ingrid Nielsen \& Russell Smyth

Vol. 15 China's Reforms at 30: Challenges and Prospects edited by Dali L Yang \& Litao Zhao

Vol. 16 Political Booms: Local Money and Power in Taiwan, East China, Thailand and the Philippines

by Lynn T White

Vol. 17 Politics of China's Environmental Protection: Problems and Progress by Chen Gang

Vol. 18 Oil in China: From Self-Reliance to Internationalization by Lim Tai Wei

Vol. 19 China's Elite Politics: Governance and Democratization by Bo Zhiyue

Vol. 20 China's New Social Policy: Initiatives for a Harmonious Society edited by Zhao Litao \& Lim Tin Seng

Vol. 21 Oil and Gas in China: The New Energy Superpower's Relations with Its Region by Lim Tai Wei

Vol. 22 China and The Global Economic Crisis edited by Zheng Yongnian \& Sarah Y. Tong

Vol. 23 Social Cohesion in Greater China: Challenges for Social Policy and Governance edited by Ka Ho Mok \& Yeun-Wen Ku

Vol. 24 China's Reform in Global Perspective edited by John Wong \& Zhiyue Bo

Vol. 25 The Transition Study of Postsocialist China: An Ethnographic Study of a Model Community by Wing-Chung Ho

Vol. 26 Looking North, Looking South: China, Taiwan, and the South Pacific edited by Anne-Marie Brady 


\section{Published by}

World Scientific Publishing Co. Pte. Ltd.

5 Toh Tuck Link, Singapore 596224

USA office: 27 Warren Street, Suite 401-402, Hackensack, NJ 07601

UK office: 57 Shelton Street, Covent Garden, London WC2H 9HE

\section{British Library Cataloguing-in-Publication Data}

A catalogue record for this book is available from the British Library.

\section{Series on Contemporary China - Vol. 26 LOOKING NORTH, LOOKING SOUTH China, Taiwan, and the South Pacific}

Copyright $@ 2010$ by World Scientific Publishing Co. Pte. Ltd.

All rights reserved. This book, or parts thereof, may not be reproduced in any form or by any means, electronic or mechanical, including photocopying, recording or any information storage and retrieval system now known or to be invented, without written permission from the Publisher.

For photocopying of material in this volume, please pay a copying fee through the Copyright Clearance Center, Inc., 222 Rosewood Drive, Danvers, MA 01923, USA. In this case permission to photocopy is not required from the publisher.

ISBN-13 978-981-4304-38-2

ISBN-10 981-4304-38-7

Printed in Singapore. 


\section{CONTENTS}

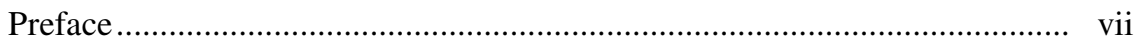
Anne-Marie Brady

About the Authors XV

\section{Part One: China and Taiwan's South Pacific Rivalry}

1. The South Pacific: China's New Frontier.................................................. 3 Bertil Lintner

2. The Software of China-Pacific Island Relations 35 Ron Crocombe

3. Sino-Pacifica: Extra-Territorial Influence and the Overseas Chinese 49 James Jiann Hua To

4. China: Stumbling Through the Pacific?

Fergus Hanson

5. The Security Implications of Cross-Strait Competition in the South Pacific from a Taiwanese Perspective. Cheng-yi Lin

\section{Part Two: The Impact on Other Key Pacific Players}

6. Rising Chinese Influence in the South Pacific: Beijing's Island Fever .... 137 Tamara Renee Shie

7. Big Trouble in Little Chinatown: Australia, Taiwan and the April 2006 Post-Election Riot in Solomon Islands

Joel Atkinson

8. New Zealand, the Pacific and China: The Challenges Ahead 189 Anne-Marie Brady and John Henderson 


\section{Part Three: Chinese Foreign Policy in the Pacific: Two Perspectives}

9. Chinese Foreign Policy in Asia: Implications for the South Pacific Phillip C. Saunders

10. The South Pacific in China's Grand Strategy.....

Jian Yang

Index 


\section{PREFACE}

Looking North, Looking South brings together the work of leading China, Taiwan, and Pacific politics specialists to analyse a topic of growing importance: China and Taiwan's ever-growing involvement in the South Pacific. The book covers this fascinating and topical subject from a range of angles and perspectives. In order to explore the complexity and differing perspectives on the significance of the issue, Looking North, Looking South incorporates a wide range of representative views. The aim of the book is not to come down on one side or the other of the arguments about China and Taiwan's activities in the region, but rather to let the reader come to their own conclusions.

China is on the rise in Asia, Africa, South America, the Caribbean, even Antarctica and the Arctic. China's activities in the South Pacific are part of this rise. Looking North, Looking South locates China's involvement in the South Pacific within the context of China's wider foreign policy and the challenges it poses to the traditional dominant powers of the region. Despite the importance of the topic, there is no other comparable book in print.

In contrast to China, Taiwan (still formally known as the Republic of China) is on the decline on the international stage, since the People's Republic of China now claims the recognition of most countries of the world as "One China". Only 23 countries continue to recognise the ROC, which makes the six nations in the South Pacific who have diplomatic relations with Taiwan disproportionately important to both the ROC and the PRC. 
The China-Taiwan rivalry has helped to alter the balance of traditional influence in the South Pacific. China is now one of the largest aid donors in the region, and is increasingly squeezing out Australia, New Zealand, and the United States, both in terms of influence and funding. Yet despite this, contradictorily, Australia, New Zealand, and the United States rely heavily on the Chinese economy for their ongoing prosperity. China offers both challenges and opportunities to these nations and the micro states of the South Pacific.

Looking North, Looking South is organised thematically into three sections. The first section discusses China and Taiwan's South Pacific rivalry. The second section analyses the impact of China and Taiwan's activities on other key Pacific players. The third and final section provides two contrasting perspectives on Chinese foreign policy in the Pacific. Many of the papers originated in a conference with the same themes held at the University of Canterbury, Christchurch, New Zealand, in June 2008. The other authors were invited to join the book project in order to represent as wide a range of ideas on China's activities in the South Pacific as possible.

The first section of the book fills in the detail of the claim that China is on the rise in the South Pacific. In the first chapter, veteran AsiaPacific journalist, Bertil Lintner argues that China is expanding its influence over the South Pacific region with the long-term aim of challenging the traditional powers in the South Pacific. Lintner draws on a fascinating series of examples from his extensive reporting of South Pacific affairs to illustrate his argument. Lintner asserts that since many of the Pacific nations recognise Taiwan, the Republic of China (ROC), it is in the interest of the People's Republic of China (PRC) to be involved in the South Pacific in order to deny the island its claim to legitimacy. However, according to Lintner, while competing with Taiwan for diplomatic recognition, Beijing is also laying the groundwork for a future contest between the United States and China for supremacy in the Pacific Ocean, the "buffer" between China and North America. At the same time, Chinese migration to the region has resulted in anti-Chinese riots in island nations such as Tonga, the Solomon Islands and Papua New Guinea, further contributing to the volatility of the region. Bertil says the South Pacific is changing, it is no longer the peaceful backwater it once 
was, and China's increased involvement in the region is part of the reasons for this.

The second chapter is by emeritus professor Ron Crocombe, who sadly passed away while this volume was being edited. Professor Crocombe's contribution is brief and to the point. Crocombe asserts that the "hardware" of China-Pacific Islands relations is well known, such as the growing exports of Pacific Islands minerals, timber, fish and agricultural products to China; the rapid increase in imports of Chinese manufactured goods; and the growing proportion of foreign aid to the Islands that comes from China. However what Crocombe calls the "software" of burgeoning China-Pacific interactions is less well understood. Crocombe divides this "software" up into ten different categories-religion; language; Sino-Pacific ethnic connections; media links; educational links; social and personal relations; tourism; similarities in value systems; approaches to governance; and the evolving new architecture of regional organization. Crocombe concludes with a warning that Pacific peoples must take on the challenge of better understanding China (and Asia in general), because he says, in future that will be the main external influence in the South Pacific.

The third chapter in this section of the book by James To details the Overseas Chinese communities' presence in the South Pacific; how both China and Taiwan attempt to maintain links with it; and, in the case of China, attempts to "manage" its allegiance. The Overseas Chinese community (OC) continues to be a significant channel for China's extension of its national interests abroad. To argues that the $\mathrm{OC}$ are specifically targeted and mobilized by China as a means of advancing two of its key national interests around the world: increasing China's soft-power and improving its image as a global citizen. While there are long-standing Chinese communities in many South Pacific countries, in recent years there has been a dramatic increase in illegal immigration. To outlines China's attitude towards illegal and legal migration and its strategies for reaching out to both new and more established migrants. To says China's attitude towards the Overseas Chinese in the Pacific reflects one of the main strategic goals for its involvement in the region: isolating Taiwan. China actively seeks to exert influence amongst OC 
communities in the Pacific in an effort to isolate and challenge political threats such as Taiwan and the independence movement.

In the fourth chapter of this section Fergus Hanson provides detailed statistics on the extent of China's aid assistance to the South Pacific and its overall strategy in dealing with the region. Hanson argues that China's expanding influence in the Pacific region is less a well-thought out plan than a series of short-term objectives, focused on checking and reversing Taiwan's diplomatic relations in the region. He notes that this approach both tends to undermine Pacific development objectives, as well as China's own medium and long-term interests in the region. Hanson concludes his chapter with an assessment of the outlook for China's engagement with the Pacific and suggested recommendations for change.

The fifth chapter of this section looks at the China-Taiwan rivalry in the South Pacific from the point of view of Taiwan. Lin Cheng-yi states that the South Pacific has become increasingly important to Taiwan in recent years. Taiwan has six diplomatic posts in the region, so more than a quarter of all the countries that recognise the Republic of China on Taiwan are located in the South Pacific. China and Taiwan have both established dialogue partnerships with the Pacific Islands Forum even though Taiwan's status is not fully recognized. Rivalries between China and Taiwan have caused some island states to bet their best interests for economic development, leading to increasing allegations of corruption. Diplomatic considerations, geographical proximity, the richness of ocean resources, and affordable foreign aid packages have made the South Pacific a region vital to Taiwan's foreign relations. Lin states that the South Pacific-second only to Central America and the Caribbean-is now a key location for Taiwan's diplomatic recognition. Despite the diplomatic truce proposed by the Ma government in 2008, the rivalries between China and Taiwan over the South Pacific are not likely to fade away.

The second section of the book looks at the impact of China's rise in the South Pacific region on three key Pacific powers, the United States, Australia, and New Zealand. In the first chapter of this section Tamara Renee Shie examines the impact of rising Chinese influence in the South Pacific from the point of view of the United States. Shie locates China's increased presence in the South Pacific region within China's increased 
global engagement overall. Shie details China's range of activities within the South Pacific and the regional response. She considers Beijing's potential economic, political, and strategic motivations, and the implications for the US. She cautions that the US is currently being "eclipsed" in the region by China.

In the second chapter Joel Atkinson uses the experience of the 2006 riot in the Solomons to examine Australia's relations with Taiwan in the context of the South Pacific. Atkinson backgrounds Australia's and Taiwan's involvement in the South Pacific, then examines Taiwan's role in the Solomon Islands crisis and the subsequent Australian-led intervention. Atkinson discusses the involvement of the Australian and Taiwan governments in the events surrounding the April 2006 elections in Solomon Islands, the selection of Synder Rini as prime minister and the subsequent riot, the ensuing sustained public controversy between Australia and Taiwan, as well as developments concerning Australia and Taiwan during the Manasseh Sogavare government. Atkinson notes that an end to Sino-Taiwan diplomatic rivalry will not necessarily improve the situation in the Solomons, and from the Australian point of view, will mean an increase in its aid burden.

In the third chapter of this section I team up with John Henderson to look at the rising Chinese presence in the South Pacific region from the perspective of New Zealand. The paper addresses a series of questions, including: What factors generate China's growing interest in Pacific island states? How important is the issue of Taiwan? What factors are driving increased Chinese migration to the region, and what are the repercussions? How prepared is New Zealand for the paradigm shift in the Pacific from a Eurocentric to a potentially Sinocentric order? Could New Zealand interests be challenged by this shift? And how important is the Pacific to Chinese interests? These questions were originally set by a New Zealand semi-governmental agency, which for reasons of political sensitivities, must not be named here. The authors' response to these questions, this paper, proved to be too incendiary to have them published in an official paper as originally intended. The authors' conclusions appear publicly here for the first time, though they have been presented orally at academic forums in Australia, the US, China, Taiwan, and New Zealand to a positive reception. 
The final section of the book analyses Chinese foreign policy from two different perspectives. The first paper is Phillip C. Saunders' analysis of China's Asia strategy and how it relates to the South Pacific. Saunders considers how China might use its growing power in the future, and assesses how other Asian and global powers are likely to respond to a more powerful and more influential China. He also examines likely implications if current trends continue, and potential developments that might alter China's regional policy. Saunders argues that China's reassurance strategy has been remarkably successful in preserving a stable regional environment and persuading its neighbours to view China as an opportunity rather than a threat. However, despite China's restrained and constructive regional behavior over the last decade, significant concerns remain about how a stronger and less constrained China might behave in the future.

In the second chapter of this section Jian Yang critiques what he calls "'China threat' theories on the South Pacific". Yang says the South Pacific "China threat" discourse is characterised by its assertiveness and superficiality. He says that despite the claims of some analysts, there is no clear evidence to suggest that China's deepening involvement in the South Pacific is a calculated strategic move for its military security. Rather, he argues that China's main strategic interests in the region are the goal of resolving the Taiwan issue and furthering China's economic development. Yang asserts that the South Pacific has little strategic value to China's national security either at present, or in the foreseeable future. Chinese influence in the region is not deep-rooted and is largely based on its "no-strings-attached" aid and its increasing economic interactions with the region. According to Yang, China has neither the hard power, nor the soft power, to become a genuine hegemon in the region.

Looking North, Looking South offers a range of fresh perspectives on the implications of China and Taiwan's activities in the South Pacific. I am grateful to all those who have helped this book come into fruition including: John Henderson, who first invited me to work with him on the topic of China-Pacific affairs; James To, who was my able assistant in organizing the conference on the same theme as the book and liaising with potential contributors for this book project; Lara Hawke, whose sharp eye for detail helped the index come together; Shiyavanthi 
Johnpillai, with whom I have now worked on getting three books ready for publication, who was as meticulous as ever in producing a highquality proof; and Dr K.K. Phua, Chairman of World Scientific, who valued the topic and its approach and who has given his full support to this book being published. I would also like to thank my husband Z.J. for his support and encouragement throughout this whole project, which all started with a discussion paper back in 2004. I dedicate this book, with love, to our three children: Francesca, Silas, and Matteo.

Anne-Marie Brady 
This page is intentionally left blank 


\section{ABOUT THE AUTHORS}

Joel Atkinson is currently a visiting professor, Department of International Relations at University of Seoul, Korea.

Anne-Marie Brady is an Associate-Professor in Political Science at the University of Canterbury, in Christchurch, New Zealand, specialising in Chinese politics.

Ron Crocombe was, until his death in 2009, the leading expert on Pacific affairs.

Fergus Hanson is a Researcher at the Lowy Institute in Sydney, Australia.

John Henderson is an Associate-Professor in the Political Science Programme at the University of Canterbury, in Christchurch, New Zealand and a leading expert on Oceanic politics and New Zealand foreign policy.

Cheng-yi Lin is a Senior Researcher at the Academia Sinica in Taiwan.

Bertil Lintner is a world-renowned journalist specialising in the AsiaPacific region.

Phillip C. Saunders is a Senior Researcher at the Institute for National Strategic Studies, in the National Defense University, Washington, DC, USA. 
Tamara Renee Shie is a political analyst at the US Embassy, in Jakarta, Indonesia.

James To is a doctoral candidate in the Political Science Programme, at the University of Canterbury, in Christchurch, New Zealand.

Jian Yang is a Senior Lecturer in the Political Studies Department of the University of Auckland, in Auckland, New Zealand. 